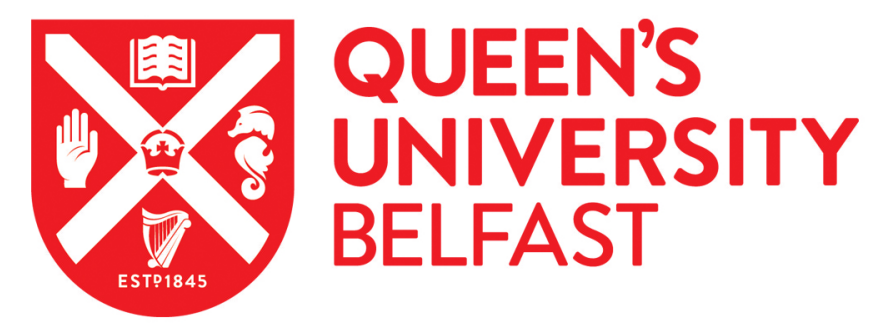

\title{
Influence of diabetes on natriuretic peptide thresholds in screening for Stage B heart failure
}

Watson, C., James, S., O'Connell, E., Gallagher, J., O'Reilly, J., Tallon, E., Baugh, J., O'Connell, J., O'Shea, D., Ledwidge, M., \& McDonald, K. (2016). Influence of diabetes on natriuretic peptide thresholds in screening for Stage B heart failure. Biomarkers, 21(6), 538-543. https://doi.org/10.3109/1354750X.2016.1160427

\section{Published in:}

Biomarkers

\section{Document Version:}

Peer reviewed version

Queen's University Belfast - Research Portal:

Link to publication record in Queen's University Belfast Research Portal

\author{
Publisher rights \\ (C) 2016 Informa UK Limited, an Informa Group Company \\ This is an Accepted Manuscript of an article published by Taylor \& Francis in Biomarkers on 06 Apr 2016, available online: \\ http://www.tandfonline.com/doi/full/10.3109/1354750X.2016.1160427
}

\section{General rights}

Copyright for the publications made accessible via the Queen's University Belfast Research Portal is retained by the author(s) and / or other copyright owners and it is a condition of accessing these publications that users recognise and abide by the legal requirements associated with these rights.

\footnotetext{
Take down policy

The Research Portal is Queen's institutional repository that provides access to Queen's research output. Every effort has been made to ensure that content in the Research Portal does not infringe any person's rights, or applicable UK laws. If you discover content in the Research Portal that you believe breaches copyright or violates any law, please contact openaccess@qub.ac.uk.
} 
Title:

Influence of diabetes on natriuretic peptide thresholds in screening for Stage B heart failure

\section{Authors:}

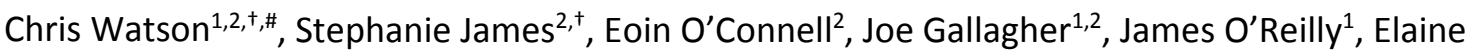
Tallon $^{2}$, John Baugh ${ }^{1}$, Jean O' Connell ${ }^{3}$, Donal O'Shea ${ }^{3}$, Mark Ledwidge ${ }^{1,2}$, Ken McDonald ${ }^{1,2}$

\section{Affiliations:}

${ }^{1}$ Wellcome-Wolfson Building, Centre for Experimental Medicine, Queen's University Belfast, Northern Ireland.

${ }^{2}$ Chronic Cardiovascular Disease Management Group, St Vincent's University Hospital Healthcare Group, Dublin, Ireland.

${ }^{3}$ School of Medicine, University College Dublin, Belfield, Dublin, Ireland.

${ }^{4}$ Department of Endocrinology, St Vincent's University Hospital Healthcare Group, Elm Park, Dublin 4 ${ }^{\dagger}$ Equal contribution

"Corresponding author

\section{Address for correspondence:}

Dr Chris Watson, Wellcome-Wolfson Building, Centre for Experimental Medicine, Queen's University Belfast, Northern Ireland. E-mail chris.watson@qub.ac.uk;

Tel. +44 2890976478.

Key words: diabetes mellitus; cardiovascular disease; ventricular dysfunction; cardiac biomarker; btype natriuretic peptide 


\section{Abstract:}

Context

Natriuretic peptide (NP) has been shown to be an effective screening tool to identify patients with Stage $B$ heart failure and to have clinical value in preventing heart failure progression. The impact of associated metabolic confounders on the screening utility of NP needs clarification.

Objective

To assess the impact of diabetes (DM) on NP screening for asymptomatic Stage B heart failure.

Materials and Methods

The study population consisted of 1368 asymptomatic patients with cardiovascular risk factors recruited from general practice as part of the STOP-HF trial. B-type NP (BNP) was quantified at pointof-care.

Results

BNP was found to be as accurate for detecting Stage $B$ heart failure in DM patients compared to non-DM patients (AUC $0.75[0.71,0.78]$ and $0.77[0.72,0.82]$, respectively). However, different BNP thresholds are required to achieve the same level of diagnostic sensitivity in DM compared with nonDM patients. To achieve $80 \%$ sensitivity a difference of $5 \mathrm{ng} / \mathrm{L}$ lower is required for patients with diabetes.

Conclusion

Although a significantly different BNP threshold is detected for patients with DM, the BNP concentration difference is small and unlikely to warrant a clinically different diagnostic threshold. 


\section{Background:}

The prevalence of heart failure is set to increase by $25 \%$ between now and 2030 , with an associated 2.5 fold increase in medical costs from $\$ 21$ to $\$ 53$ billion (Rathi and Deedwania, 2012). These concerning epidemiological trends are driven by many factors, including the epidemic of diabetes mellitus with data demonstrating up to a five-fold increase of incident heart failure among women and two-fold among men with diabetes(Kannel et al., 1974). These findings highlight the need to focus on prevention of heart failure and in particular directing such prevention strategies at those with diabetes.

An essential component of an effective prevention strategy for heart failure is the ability to identify those at heightened risk from the general at risk cohort. Such a group are patients with features of asymptomatic left ventricular abnormalities (Stage B Heart Failure). Previous work from our unit and others have shown that, while limitations exist, natriuretic peptide (NP) is an effective screening tool to identify this population(Vasan et al., 2002, Maisel et al., 2001, Murtagh et al., 2012, Krishnaswamy et al., 2001, Lubien et al., 2002, Nadir et al., 2015, Chahal et al., 2015, Hebert et al., 2010). In addition, risk stratification with NP can facilitate strategies guided by NP, which have been shown to be effective in reducing new onset heart failure and other cardiovascular (CV) events (Ledwidge et al., 2013, Huelsmann et al., 2013).

There are good data to suggest that NP role as a screening tool for Stage B could be altered by the metabolic status of the diabetic patient, Insulin levels, obesity (Khan et al., 2011, Wang et al., 2004, Sugisawa et al., 2010) and the impact of glycosylation on NP processing and detection may all play a role (Semenov et al., 2010, Semenov et al., 2009, Vodovar et al., 2014). Clarification of the interaction between NP and diabetes is essential if we are to effectively apply this peptide in a screening process. Using the STOP-HF (Ledwidge et al., 2013) (The St Vincent's Screening to Prevent Heart Failure Study) population we set out to address the hypothesis that NP is as effective in Stage $B$ screening in a DM cohort compared to a non-DM cohort, but due to metabolic influence of the diabetic state on NP that the threshold values for the peptide would be significantly altered.

\section{Methods:}

\section{Patient Sample}

The study population consisted of 1368 patients from within the STOP-HF cohort, described in detail elsewhere (Ledwidge et al., 2013). In brief, the STOP-HF cohort (universal trial number:

NCT00921960) is a population with cardiovascular risk factors, recruited from primary care practices in Ireland. Age $\geq 40$ years and at least one risk factor for left ventricular dysfunction including: type 2 diabetes mellitus (DM); hypertension; obesity; hypercholesterolemia; or coronary artery disease. DM was defined as fasting plasma glucose $\geq 7.0 \mathrm{mmol} / \mathrm{L}$ or $2 \mathrm{~h}$ post-load plasma glucose of 11.1 $\mathrm{mmol} / \mathrm{L}$. All subjects gave written informed consent to participate in this cohort. The study protocol was approved by the ethics committee of St. Vincent's University Hospital, which conformed to the principles of the Helsinki Declaration.

\section{Clinical Assessment}

At clinical visits, a full physical examination, New York Heart Association (NYHA) functional class assessment, and phlebotomy were performed by a blinded observer. Physical examination included 
assessment of waist circumference, BMI calculation, heart rate and blood pressure measurement. Peripheral venous blood samples were tested for levels of creatinine, glucose, and lipid profile. Point of care B-type natriuretic peptide (BNP) was measured at each visit using a Triage meter (Biosite). Assay sensitivity for BNP was $5 \mathrm{ng} / \mathrm{l}$. All patients had baseline electrocardiograms (ECGs) performed.

\section{Doppler Echocardiography}

Doppler echocardiographic assessment was performed by one of two blinded operators, in accordance with the American Society of Echocardiography recommendations. All data represent the mean of three measurements on sequential cardiac cycles. Left ventricular mass was calculated using the Devereux method and was indexed to body surface area. Left atrial volume was calculated using the biplane area length method and was also indexed to body surface area. Left ventricular filling pressures were non-invasively assessed by tissue Doppler measurements taken at the lateral mitral annulus. Left ventricular ejection fraction was calculated by the Teichholz method. Classification of left ventricular diastolic dysfunction (LVDD) was based on having both a left atrial volume index $(\mathrm{LAVi}) \geq 34 \mathrm{ml} / \mathrm{m}^{2}$ and a tissue lateral $\mathrm{e}^{\prime}$ value $\leq 10 \mathrm{~cm} / \mathrm{sec}$. In patients with atrial fibrillation the tissue Doppler value alone was used to define LVDD. Left ventricular systolic dysfunction (LVSD) was defined as an ejection fraction $<50 \%$. Cut-off values for moderate to severe increase in left ventricular mass were $132 \mathrm{~g} / \mathrm{m}^{2}$ in male and $109 \mathrm{~g} / \mathrm{m}^{2}$ in females. Stage B heart failure was defined as meeting one or more of these three criteria.

\section{Statistical Analysis}

For the purpose of this study, data from first visit after $1^{\text {st }}$ January 2010 were used, including echocardiography and associated clinical visit, which consisted of a point of care BNP measurement, to investigate LVDD prediction.

Generalised Linear Modelling with a binomial outcome of Stage B heart failure was used for all modelling. Predicted probabilities from those models were used to calculate the ROC curves in figure 2 alongside the raw BNP ROC curves, with 95\%-Cls presented in parentheses. No transformations were used and all calculations were carried out using $R$ Language version 2.7.2.

\section{$\underline{\text { Results }}$}

\section{Patient characteristics of study cohort (Table 1).}

The study cohort consisted of 966 non-diabetic patients and 402 type 2 diabetic patients. A number of anthropometric, biochemical and medication differences exist between these patient groups and are highlighted in Table 1. Of note, median BNP levels were significantly lower in the diabetic group.

\section{BNP screening for Stage $B$ heart failure.}

The utility of BNP to screen for Stage B heart failure was assessed using ROC curves for the DM and non-DM subsamples, which yielded AUCs of $0.75[0.71,0.78]$ and $0.77[0.72,0.82]$ respectively, (Figure 1). Although the AUC is slightly greater in the non-DM subsample, it is not a significant difference as the confidence intervals share a large overlap. Additionally, the difference between the two subsamples appears mainly due to DM losses at the sensitivity $<60 \%$ end of the ROC curve 
(Figure 1). As we are interested in performance at the higher sensitivities for screening purposes, any slightly apparent AUC difference can be ignored.

\section{Utility of applying different BNP thresholds in screening for Stage B heart failure.}

To achieve sensitivity of approximately $70-90 \%$ for detecting Stage B heart failure a BNP concentration range of $10-30 \mathrm{ng} / \mathrm{L}$ is appropriate, as presented in Figure 1. Similar sensitivities and specificities can be achieved in both DM and non-DM populations but requires different BNP cut-off thresholds. The BNP thresholds in the DM subsample are approximately $5 \mathrm{ng} / \mathrm{L}$ lower than in the non-DM subsample (Figure 1) at equivalent sensitivities. For example, using a BNP threshold of 25 $\mathrm{ng} / \mathrm{L}$ gives approximately $81 \%$ sensitivity with $61 \%$ specificity in the non-DM subsample. That same threshold applied to the DM subsample yields $72 \%$ sensitivity and $69 \%$ specificity. Deducting $5 \mathrm{ng} / \mathrm{L}$ from the threshold for DM subsample in this case gives $78 \%$ sensitivity and $62 \%$ specificity, which brings performance more in line with non-DM patients.

\section{Co-variate adjusted models of BNP screening for Stage B heart failure.}

As highlighted in Table 1, age, gender and BMI were significantly different between the DM and nonDM subsamples. The benefit of including these as covariates to predict Stage B heart failure using BNP was assessed (Figure 2). The strength of the multivariate equation in identifying Stage B heart failure was not significantly better than BNP alone, as indicated by AUC values and associated confidence intervals. This was the case whether looking at the total cohort or dividing down into the two subsamples of DM and non-DM. The resulting specificity at a target sensitivity of $80 \%$ in each of the ROC curves is also given in Figure 2 for comparison.

\section{Utility of diabetes specific BNP threshold for Stage B heart failure screening}

Using a required sensitivity of $80 \%$, comparison of the impact of utilizing separate BNP thresholds ( $25 \mathrm{ng} / \mathrm{L}$ non-DM \& $20 \mathrm{ng} / \mathrm{L} \mathrm{DM}$ ) versus a single BNP value $(25 \mathrm{ng} / \mathrm{L}$ ) in the study cohort of 1365 patients for hypothetical referral and detection is shown in Table 2. When applying the single BNP threshold, 612 patients were referred for echocardiography of which 203 had Stage B heart failure, and 56 patients with Stage B were missed. When applying separate BNP thresholds based on DM status, an additional 25 patients were referred for echocardiography, of which 5 had Stage B heart failure.

\section{Discussion:}

This study examined the utility of B-type natriuretic peptide (BNP) in screening Stage B heart failure in diabetic (DM) and non-diabetic (non-DM) population samples. Within the STOP-HF cohort it was found that BNP is as accurate for detecting Stage B heart failure in DM patients compared to nonDM patients with AUCs of 0.75 and 0.77 , respectively. However, threshold values to yield $80 \%$ sensitivity differed between the two cohorts with a $5 \mathrm{ng} / \mathrm{L}$ lower value required for patients with diabetes. Using different screening thresholds for these two populations resulted in a modest increase in patient number referred for echocardiography and a small reduction in false negative screens. 
Maximising diagnostic accuracies for Stage B heart failure is important, as this large cohort provides the optimal stage in the natural history of ventricular dysfunction to apply preventative strategies to reduce new onset heart failure (Ammar et al., 2007). Routine and repeat use of echocardiography or other imaging investigations for this purpose is not practical. Natriuretic peptide has been shown by many groups to be a useful biomarker to screen for significant ventricular dysfunction in the general at-risk population. This includes work by Hebert and colleagues who investigated the utility of BNP as a pre-screen for echocardiography in diabetic patients with Stage B heart failure, as defined in this study by left ventricular systolic dysfunction ( $E F<55 \%$ ) (Hebert et al., 2010).

However, there is some debate as to whether NP would be an effective screening tool for Stage B heart failure among patients with diabetes. Various mechanisms have been described that could result in reduced circulating levels of the protective natriuretic peptide hormone in patients with DM, mainly been attributed to dysregulation of natriuretic peptide (NP) metabolism. Diabetes and insulin resistance have been shown to have an effect on BNP levels previously in different study cohorts. Khan et al. have shown a 10-30\% decrease in BNP levels associated with insulin (Khan et al., 2011). In addition, insulin has recently been linked to an upregulation of the NP clearance receptor, natriuretic peptide receptor C (NPRC), in adipocytes and monocytes in the subcutaneous adipose tissue of obese, insulin resistant patients (Pivovarova et al., 2012). With obesity being a prominent feature in type 2 diabetic populations, it is important to note that obesity-linked upregulation in adipocyte NPRC has also been observed in humans to be associated with an increased clearance of NP, but this predominantly affects BNP, in part cleared by this receptor and not NTproBNP which is dominantly cleared by the kidney (Dessi-Fulgheri et al., 1997). It has recently been shown that weight loss in obese patients results in a significant elevation in natriuretic peptides (Arora et al., 2015).

An additional mechanism by which circulating NP levels could be altered in diabetic populations is via post-translation modification changes affecting its production or metabolism. Recent data has shown that BNP and the enzymes involved in its processing (furin and corin) can undergo glycosylation profile changes in heart failure, or be implicated in its processing (Semenov et al., 2010, Semenov et al., 2009, Vodovar et al., 2014, Ichiki et al., 2013, Peng et al., 2011). It has been suggested recently that under normal conditions proBNP is glycosylated as mechanism to limit its processing to functional BNP, and during heart failure the degree of proBNP glycosylation is reduced which results in an increase in proBNP processing to active BNP (Vodovar et al., 2014). In the context of diabetes it has been shown that serum and tissue glycosylation signatures differ compared with non-diabetic profiles (Testa et al., 2015, Ravida et al., 2015). Therefore a possible link may exist between glycosylation mediated reduction in circulating BNP in diabetics compared with non-diabetics in a Stage B heart failure population, a concept that would warrant investigation.

With this background our study found similar diagnostic accuracies for detecting Stage B heart failure, but we also report for the first time that different BNP thresholds are required to achieve the same level of diagnostic sensitivity in DM compared with non-DM patients. As anticipated, and based on the aforementioned data, a $5 \mathrm{ng} / \mathrm{L}$ lower cut-off for diabetic patients is required to maintain equivalent accuracy compared with the non-diabetic cohort. The application of distinct thresholds results in a modest $2 \%$ improvement in screening sensitivity. However, the clinical relevance of applying this difference is questionable given that the known variability of NP on a dayto-day basis is likely greater than the noted difference of $5 \mathrm{ng} / \mathrm{L}$. Therefore, it may be practically 
more effective to have the same NP cut-off irrespective of DM status of a patient. It is also interesting to speculate that the lower levels of NP noted in the diabetic cohort may in part explain the increased susceptibility of patients with diabetes to heart failure. Finally, the specific factors that could account for these different thresholds are not investigated fully in this study, but could be due to factors such as obesity and age (Jan et al., 2013, Dessi-Fulgheri et al., 1997, Arora et al., 2015). Although these factors may influence the selected BNP threshold to detect Stage B heart failure at a given sensitivity, they do not alter BNP's ability to correctly classify patients within this population. Therefore generation and application of thresholds for other populations may be influenced by the representation of obesity within the diabetic cohort, or the age profile of the patients.

\title{
Conclusion
}

Although the mechanism by which a reduction in detectable circulating BNP in the diabetic cohort is observed, it is likely to be related to multifactorial influences. Whether or not these resultant significant differences in BNP expression levels in diabetic patients warrants its clinical translation into a personalised BNP threshold for Stage B heart failure prediction requires further validation along with economic modelling studies based on improved correct classification through separate screening thresholds.

\section{Limitations}

There are several limitations to consider when interpreting the findings of this study. All the data presented are from a single population, pre-selected so that recruited study patients have at least one cardiovascular disease risk factor. BNP thresholds and diagnostic accuracies for Stage B heart failure may vary among different populations, particularly when the metabolic profile differs. In this study we do not consider the added value of serial BNP measurements in disease prediction. Collectively, our findings should encourage the approach of a personalised BNP threshold for predicting structural and functional abnormalities of the heart to be explored further.

\author{
Abbreviations \\ BNP = b-type natriuretic peptide \\ $\mathrm{CV}=$ cardiovascular \\ $\mathrm{DM}=$ diabetes mellitus \\ $\mathrm{HF}=$ heart failure \\ LVDD = left ventricular diastolic dysfunction \\ LVSD = left ventricular systolic dysfunction \\ $\mathrm{NP}=$ natriuretic peptide
}




\section{Acknowledgements:}

This work was supported by the Health Research Board of Ireland and the European Commission FP7 project FIBRO-TARGETS [grant numbers CSA-2012-36; 602904, respectively]

\section{Competing interests:}

Conflict of Interest: none declared. 


\section{$\underline{\text { References }}$}

AMMAR, K. A., JACOBSEN, S. J., MAHONEY, D. W., KORS, J. A., REDFIELD, M. M., BURNETT, J. C., JR. \& RODEHEFFER, R. J. 2007. Prevalence and prognostic significance of heart failure stages: application of the American College of Cardiology/American Heart Association heart failure staging criteria in the community. Circulation, 115, 1563-70.

ARORA, P., REINGOLD, J., BAGGISH, A., GUANAGA, D. P., WU, C., GHORBANI, A., SONG, Y., CHENTOURNAUX, A., KHAN, A. M., TAINSH, L. T., BUYS, E. S., WILLIAMS, J. S., HEUBLEIN, D. M., BURNETT, J. C., SEMIGRAN, M. J., BLOCH, K. D., SCHERRER-CROSBIE, M., NEWTON-CHEH, C., KAPLAN, L. M. \& WANG, T. J. 2015. Weight loss, saline loading, and the natriuretic peptide system. J Am Heart Assoc, 4, e001265.

CHAHAL, H., BLUEMKE, D. A., WU, C. O., MCCLELLAND, R., LIU, K., SHEA, S. J., BURKE, G., BALFOUR, P., HERRINGTON, D., SHI, P., POST, W., OLSON, J., WATSON, K. E., FOLSOM, A. R. \& LIMA, J. A. 2015. Heart failure risk prediction in the Multi-Ethnic Study of Atherosclerosis. Heart, 101, 58-64.

DESSI-FULGHERI, P., SARZANI, R., TAMBURRINI, P., MORACA, A., ESPINOSA, E., COLA, G., GIANTOMASSI, L. \& RAPPELLI, A. 1997. Plasma atrial natriuretic peptide and natriuretic peptide receptor gene expression in adipose tissue of normotensive and hypertensive obese patients. J Hypertens, 15, 1695-9.

HEBERT, K., HORSWELL, R., HEIDENREICH, P., MIRANDA, J. \& ARCEMENT, L. 2010. Handheld ultrasound, B-natriuretic peptide for screening stage B heart failure. South Med J, 103, 61622.

HUELSMANN, M., NEUHOLD, S., RESL, M., STRUNK, G., BRATH, H., FRANCESCONI, C., ADLBRECHT, C., PRAGER, R., LUGER, A., PACHER, R. \& CLODI, M. 2013. PONTIAC (NT-proBNP selected prevention of cardiac events in a population of diabetic patients without a history of cardiac disease): a prospective randomized controlled trial. J Am Coll Cardiol, 62, 1365-72.

ICHIKI, T., HUNTLEY, B. K. \& BURNETT, J. C., JR. 2013. BNP molecular forms and processing by the cardiac serine protease corin. Adv Clin Chem, 61, 1-31.

JAN, A., DAWKINS, I., MURPHY, N., COLLIER, P., BAUGH, J., LEDWIDGE, M., MCDONALD, K. \& WATSON, C. J. 2013. Associates of an elevated natriuretic peptide level in stable heart failure patients: implications for targeted management. ScientificWorldJournal, 2013, 562763.

KANNEL, W. B., HJORTLAND, M. \& CASTELLI, W. P. 1974. Role of diabetes in congestive heart failure: the Framingham study. Am J Cardiol, 34, 29-34.

KHAN, A. M., CHENG, S., MAGNUSSON, M., LARSON, M. G., NEWTON-CHEH, C., MCCABE, E. L., COVIELLO, A. D., FLOREZ, J. C., FOX, C. S., LEVY, D., ROBINS, S. J., ARORA, P., BHASIN, S., LAM, C. S., VASAN, R. S., MELANDER, O. \& WANG, T. J. 2011. Cardiac natriuretic peptides, obesity, and insulin resistance: evidence from two community-based studies. J Clin Endocrinol Metab, 96, 3242-9.

KRISHNASWAMY, P., LUBIEN, E., CLOPTON, P., KOON, J., KAZANEGRA, R., WANNER, E., GARDETTO, N., GARCIA, A., DEMARIA, A. \& MAISEL, A. S. 2001. Utility of B-natriuretic peptide levels in identifying patients with left ventricular systolic or diastolic dysfunction. Am J Med, 111, 274-9.

LEDWIDGE, M., GALLAGHER, J., CONLON, C., TALLON, E., O'CONNELL, E., DAWKINS, I., WATSON, C., O'HANLON, R., BERMINGHAM, M., PATLE, A., BADABHAGNI, M. R., MURTAGH, G., VOON, V., TILSON, L., BARRY, M., MCDONALD, L., MAURER, B. \& MCDONALD, K. 2013. Natriuretic peptide-based screening and collaborative care for heart failure: the STOP-HF randomized trial. JAMA, 310, 66-74.

LUBIEN, E., DEMARIA, A., KRISHNASWAMY, P., CLOPTON, P., KOON, J., KAZANEGRA, R., GARDETTO, N., WANNER, E. \& MAISEL, A. S. 2002. Utility of B-natriuretic peptide in detecting diastolic dysfunction: comparison with Doppler velocity recordings. Circulation, 105, 595-601.

MAISEL, A. S., KOON, J., KRISHNASWAMY, P., KAZENEGRA, R., CLOPTON, P., GARDETTO, N., MORRISEY, R., GARCIA, A., CHIU, A. \& DE MARIA, A. 2001. Utility of B-natriuretic peptide as a 
rapid, point-of-care test for screening patients undergoing echocardiography to determine left ventricular dysfunction. Am Heart J, 141, 367-74.

MURTAGH, G., DAWKINS, I. R., O'CONNELL, R., BADABHAGNI, M., PATEL, A., TALLON, E., O'HANLON, R., LEDWIDGE, M. T. \& MCDONALD, K. M. 2012. Screening to prevent heart failure (STOP$\mathrm{HF}$ ): expanding the focus beyond asymptomatic left ventricular systolic dysfunction. Eur J Heart Fail, 14, 480-6.

NADIR, M. A., GANDY, S., IRELAND, S., MACDONALD, T., DOW, E., HOUSTON, G., LANG, C. \& STRUTHERS, A. 2015. An increased B-type natriuretic peptide in the absence of a cardiac abnormality identifies those whose left ventricular mass will increase over time. JACC Heart Fail, 3, 87-93.

PENG, J., JIANG, J., WANG, W., QI, X., SUN, X. L. \& WU, Q. 2011. Glycosylation and processing of proB-type natriuretic peptide in cardiomyocytes. Biochem Biophys Res Commun, 411, 593-8.

PIVOVAROVA, O., GÖGEBAKAN, Ö., KLÖTING, N., SPARWASSER, A., WEICKERT, M. O., HADDAD, I., NIKIFOROVA, V. J., BERGMANN, A., KRUSE, M. \& SELTMANN, A.-C. 2012. Insulin up-regulates natriuretic peptide clearance receptor expression in the subcutaneous fat depot in obese subjects: a missing link between CVD risk and obesity? Journal of Clinical Endocrinology \& Metabolism, 97, E731-E739.

RATHI, S. \& DEEDWANIA, P. C. 2012. The epidemiology and pathophysiology of heart failure. Med Clin North Am, 96, 881-90.

RAVIDA, A., MUSANTE, L., KREIVI, M., MIINALAINEN, I., BYRNE, B., SARASWAT, M., HENRY, M., MELEADY, P., CLYNES, M. \& HOLTHOFER, H. 2015. Glycosylation patterns of kidney proteins differ in rat diabetic nephropathy. Kidney Int.

SEMENOV, A. G., POSTNIKOV, A. B., TAMM, N. N., SEFERIAN, K. R., KARPOVA, N. S., BLOSHCHITSYNA, M. N., KOSHKINA, E. V., KRASNOSELSKY, M. I., SEREBRYANAYA, D. V. \& KATRUKHA, A. G. 2009. Processing of pro-brain natriuretic peptide is suppressed by O-glycosylation in the region close to the cleavage site. Clin Chem, 55, 489-98.

SEMENOV, A. G., TAMM, N. N., SEFERIAN, K. R., POSTNIKOV, A. B., KARPOVA, N. S., SEREBRYANAYA, D. V., KOSHKINA, E. V., KRASNOSELSKY, M. I. \& KATRUKHA, A. G. 2010. Processing of pro-Btype natriuretic peptide: furin and corin as candidate convertases. Clin Chem, 56, 1166-76.

SUGISAWA, T., KISHIMOTO, I., KOKUBO, Y., NAGUMO, A., MAKINO, H., MIYAMOTO, Y. \& YOSHIMASA, Y. 2010. Visceral fat is negatively associated with B-type natriuretic peptide levels in patients with advanced type 2 diabetes. Diabetes Res Clin Pract, 89, 174-80.

TESTA, R., VANHOOREN, V., BONFIGLI, A. R., BOEMI, M., OLIVIERI, F., CERIELLO, A., GENOVESE, S., SPAZZAFUMO, L., BORELLI, V., BACALINI, M. G., SALVIOLI, S., GARAGNANI, P., DEWAELE, S., LIBERT, C. \& FRANCESCHI, C. 2015. N-glycomic changes in serum proteins in type 2 diabetes mellitus correlate with complications and with metabolic syndrome parameters. PLoS One, 10, e0119983.

VASAN, R. S., BENJAMIN, E. J., LARSON, M. G., LEIP, E. P., WANG, T. J., WILSON, P. W. \& LEVY, D. 2002. Plasma natriuretic peptides for community screening for left ventricular hypertrophy and systolic dysfunction: the Framingham heart study. JAMA, 288, 1252-9.

VODOVAR, N., SERONDE, M. F., LARIBI, S., GAYAT, E., LASSUS, J., BOUKEF, R., NOUIRA, S., MANIVET, P., SAMUEL, J. L., LOGEART, D., ISHIHARA, S., COHEN SOLAL, A., JANUZZI, J. L., JR., RICHARDS, A. M., LAUNAY, J. M., MEBAZAA, A. \& NETWORK, G. 2014. Post-translational modifications enhance NT-proBNP and BNP production in acute decompensated heart failure. Eur Heart J, 35, 3434-41.

WANG, T. J., LARSON, M. G., LEVY, D., BENJAMIN, E. J., LEIP, E. P., WILSON, P. W. \& VASAN, R. S. 2004. Impact of obesity on plasma natriuretic peptide levels. Circulation, 109, 594-600. 


\section{Figure Legends:}

Figure 1: ROC curves for prediction of Stage B heart failure in DM and non-DM samples using BNP.

The utility of BNP to screen for Stage B heart failure was assessed using ROC curves for the diabetes (DM) and non-DM subsamples. Analysis yielded AUCs of $0.75[0.71,0.78]$ and $0.77[0.72,0.82]$ for the DM and non-DM populations, respectively. To achieve sensitivity of approximately $70-90 \%$ for detecting Stage B heart failure a BNP concentration range of $10-30 \mathrm{ng} / \mathrm{L}$ is appropriate. Similar sensitivities and specificities can be achieved in both DM and non-DM populations but requires different BNP cut-off thresholds. The BNP thresholds in the DM subsample are approximately $5 \mathrm{ng} / \mathrm{L}$ lower than in the non-DM subsample at similar sensitivities.

Figure 2: ROC curves for various BNP-based model prediction of Stage B heart failure.

Co-variate adjusted models of BNP screening for Stage B heart failure was assessed using age, gender and body mass index (BMI), three parameters that were significantly difference between the $D M$ and non-DM sub-samples. This was assessed in the total study population ( $A$ ), the non-DM subsample (B), and the DM sub-sample (C). The resulting specificity at a target sensitivity of $80 \%$ in each of the ROC curves is highlighted by vertical lines for comparison. The application of a multivariate model in identifying Stage B heart failure was not significantly better than BNP alone. 
Tables:

Table 1: Patient characteristics of diabetic and non-diabetic subsamples.

\begin{tabular}{|c|c|c|c|}
\hline $\begin{array}{c}\text { Median [IQR] or } \\
N(\%)\end{array}$ & Diabetic & Non-diabetic & $\mathrm{p}$-value ${ }^{\dagger}$ \\
\hline$N$ & 402 & 966 & \\
\hline Age & $65.7[58.6: 71.6]$ & $67.9[59.5: 74.7]$ & 0.004 \\
\hline Male & 261 (64.9\%) & 454 (47.0\%) & $<.001$ \\
\hline Weight (kg) & 88.7 [77.7 : 99.4] & $78.7[68.1: 89.5]$ & $<.001$ \\
\hline Height $(\mathrm{cm})$ & 171 [163 : 177] & 167 [160 : 175] & $<.001$ \\
\hline BMI & $30[27: 34]$ & 28 [25:31] & $<.001$ \\
\hline SBP & 131 [122 : 143] & 135 [124: 146] & 0.007 \\
\hline DBP & 80 [73 : 87] & 82 [74 : 88] & 0.005 \\
\hline BNP & $17[7: 46]$ & $23[11: 51]$ & $<.001$ \\
\hline $\mathrm{HDL}$ & $1.0[0.8: 1.3]$ & $1.3[1.0: 1.7]$ & $<.001$ \\
\hline Glucose & $8.8[6.9: 11.6]$ & $5.6[5.1: 6.3]$ & $<.001$ \\
\hline Triglycerides & $1.7[1.2: 2.5]$ & $1.4[1.0: 2.1]$ & $<.001$ \\
\hline $\mathrm{AA}$ & $7(1.7 \%)$ & $6(0.6 \%)$ & ns \\
\hline ARB & $129(32.1 \%)$ & 343 (35.5\%) & ns \\
\hline ACEI & $193(48.0 \%)$ & 249 (25.8\%) & $<.001$ \\
\hline Diuretic & $132(32.8 \%)$ & 321 (33.2\%) & ns \\
\hline Statin & 313 (77.9\%) & $663(68.6 \%)$ & $<.001$ \\
\hline $\mathrm{BB}$ & 137 (34.1\%) & $323(33.4 \%)$ & ns \\
\hline $\mathrm{CCB}$ & $144(35.8 \%)$ & $282(29.2 \%)$ & 0.019 \\
\hline Anti-platelet & 291 (72.4\%) & 444 (46.0\%) & $<.001$ \\
\hline HT Agent & $333(82.8 \%)$ & 775 (80.2\%) & ns \\
\hline Anti-DM & 402 (100\%) & - & - \\
\hline Insulin & $63(15.7 \%)$ & - & - \\
\hline EF & $66[61: 70]$ & $67[62: 72]$ & $<.001$ \\
\hline Lateral e' & $8[6.4: 9.8]$ & $8.2[6.6: 10]$ & ns \\
\hline Peak E & $67[57: 82]$ & $68[56: 80]$ & ns \\
\hline E / lat. e' & $8.5[6.9: 10.7]$ & $8.2[6.5: 10.2]$ & 0.04 \\
\hline LAVI & $24.8[20.8: 29.9]$ & $24.8[21.3: 30.2]$ & ns \\
\hline LVMI & 93 [81 : 108] & $90[78: 104]$ & 0.002 \\
\hline LVDD* & 50 (12.4\%) & $117(12.1 \%)$ & ns \\
\hline
\end{tabular}

$\mathrm{BMI}$, body mass index; SBP/DBP, systolic/diastolic blood pressure; BNP, b-type natriuretic peptide; HDL, high-density lipoprotein; $A C E i$, angiotensin converting enzyme inhibitor; $A R B$, angiotensin receptor blocker; $B B$, beta blocker; $C C B$, calcium channel blocker; anti-DM, diabetes medication; $E F$, ejection fraction; E/lat. e', ratio of mitral early diastolic flow velocity over tissue Doppler lateral mitral annular lengthening velocity; LAVI, left atrial volume index; LVMI, left ventricular mass index; LVDD, left ventricular diastolic dysfunction.

* LAVI $>34$ and $\mathrm{e}^{\prime}<10$, + Wilcoxon for continuous data, chi-square for binary data. 
Table 2: BNP thresholds and observed prediction measures.

\begin{tabular}{|c|c|c|c|c|c|c|c|}
\hline \multicolumn{4}{|c|}{ Single BNP Threshold (25 ng/L) } & \multicolumn{4}{|c|}{ Separate BNP Thresholds (25|20 ng/L) } \\
\hline & Passed & Referred & Total & & Passed & Referred & Total \\
\hline No Stage B & 697 & 409 & 1106 & No Stage B & 677 & 429 & 1106 \\
\hline Stage B & 56 & 203 & 259 & Stage B & 51 & 208 & 259 \\
\hline Total & 753 & 612 & 1365 & Total & 728 & 637 & 1365 \\
\hline Sensitivity & \multicolumn{3}{|c|}{$203 / 259=78.4 \%$} & Sensitivity & \multicolumn{3}{|c|}{$208 / 259=80.3 \%$} \\
\hline FPR & \multicolumn{3}{|c|}{$409 / 1106=37.0 \%$} & FPR & \multicolumn{3}{|c|}{$429 / 1106=38.8 \%$} \\
\hline Specificity & \multicolumn{3}{|c|}{$697 / 1106=63.0 \%$} & Specificity & \multicolumn{3}{|c|}{$677 / 1106=61.2 \%$} \\
\hline FNR & \multicolumn{3}{|c|}{$56 / 259=21.6 \%$} & FNR & \multicolumn{3}{|c|}{$51 / 259=19.7 \%$} \\
\hline Precision & \multicolumn{3}{|c|}{$203 / 612=33.2 \%$} & Precision & \multicolumn{3}{|c|}{$208 / 637=32.7 \%$} \\
\hline NPV & \multicolumn{3}{|c|}{$697 / 753=92.6 \%$} & NPV & \multicolumn{3}{|c|}{$677 / 728=93.0 \%$} \\
\hline Accuracy & \multicolumn{3}{|c|}{$(697+203) / 1365=65.9 \%$} & Accuracy & \multicolumn{3}{|c|}{$(677+208) / 1365=64.8 \%$} \\
\hline
\end{tabular}

FPR - false positive rate, FNR - false negative rate, NPV - negative predictive value 
Figure 1

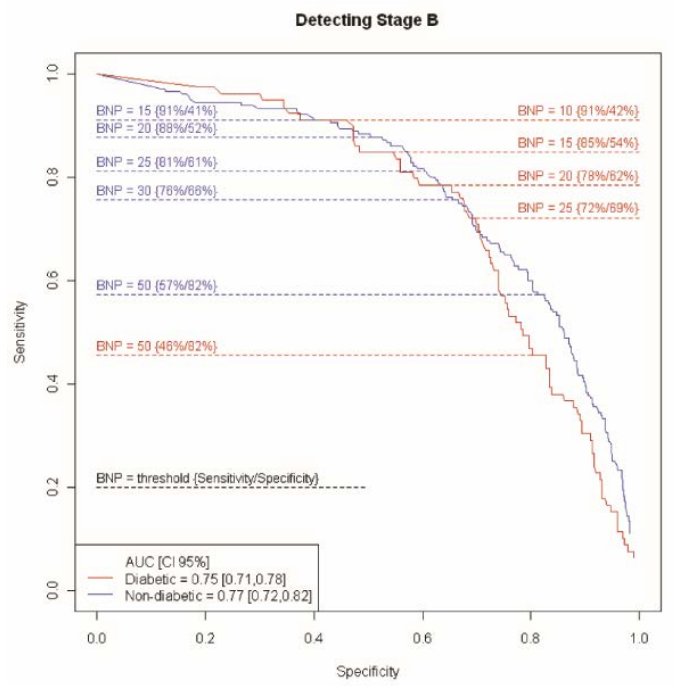


Figure 2

A

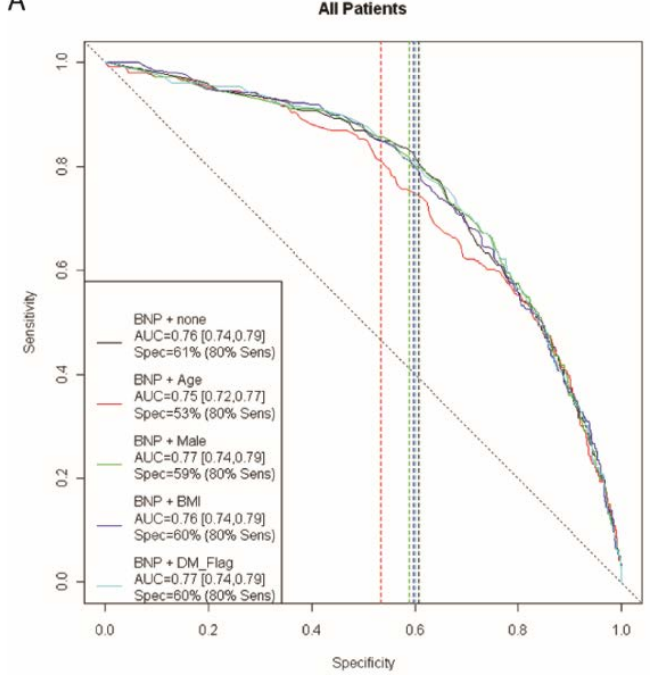

C

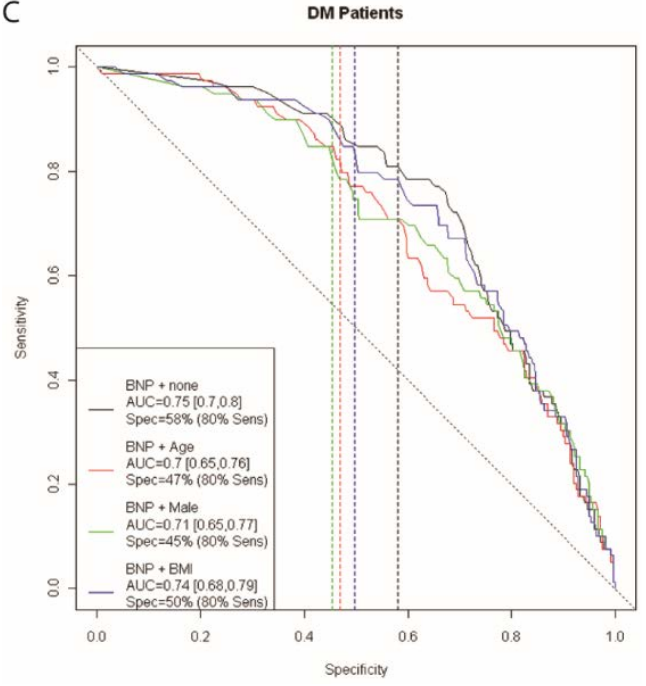

B

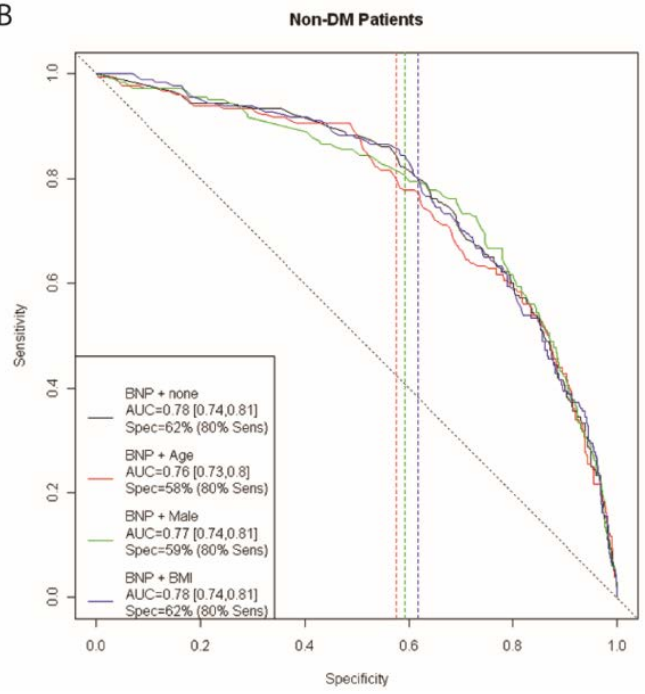

